\title{
Features of development of species of the genus Veronica L. in the conditions of steppe zone of Ukraine
}

\author{
Tatiana Chypyliak $^{1}$ (1) \& Olha Zubrovska' ${ }^{1}$
}

Key words: species of the genus Veronica L., climatic changes, Steppe of Ukraine, phenological development, leaf morphology, assemblage of rootlets.

Ključne besede: vrste rodu Veronica L., podnebne spremembe, ukrajinska stepa, fenološki razvoj, listna morfologija, koreninski splet.

Corresponding author:

Olha Zubrovska

E-mail: zubrovska@ukr.net

Received: 16. 6. 2021

Accepted: 23. 11. 2021

\begin{abstract}
The paper deals with peculiar features of development of the species Veronica L. in the conditions of the steppe zone of Ukraine (central part of the country). Under the action of climatic changes occurring for the last 20 years, the species began to grow 6-14 days earlier and increased the vegetation period by $15-25$ days. Under the effect of extreme growing conditions (hot weather and drought) decrease in the area of the leaf blade by almost 2 times was recorded in $V$. prostrata and $V$. incana. Length and width of the leaf in $V$. prostrata and $V$. incana decreased by $20-30 \%$, but in $V$. austriaca ssp. teucrium a decrease was observed for the leaf width only while its length increased by $17 \%$. Analysis of correlation of climatic factors (air temperature, precipitation amount) to the morphometric parameters of the leaf during seasonal development showed greater dependence of their value on the air temperature, which was confirmed by the inverse correlation coefficients $(r=-0.55--0.66)$. In the unfavorable growing conditions, the features of formation of the underground part of species are manifested in the inhibited development of underground shoots (by $80-85 \%$ ) and stimulation of branching and increase in the length of thin sucking roots (1.5 times). Studied species of the genus Veronica in the climatic conditions of the steppe zone of Ukraine go through all stages of phenological development and are marked by rather wide range of phenotypic changes in the vegetative sphere.
\end{abstract}

Izvleček

V članku se ukvarjamo s posebnostmi v razvoju pri vrstah rodu Veronica L. v stepskih razmerah Ukrajine (osrednji del države). Zaradi podnebnih sprememb v zadnjih 20 letih, so vrste pričele z rastjo 6-14 dni prej, vegetacijska doba pa se je podaljšala za 15-25 dni. Ovrednotili smo fenotipske spremembe listnih parametrov pod vplivom ekstremnih razmer v obdobju rasti (vroče in sušno vreme). Pri vrstah $V$. prostrata in $V$. incana smo zaznali dvakratno zmanjšanje listne površine. Dolžina in širina listov sta se pri vrstah $V$. prostrata in $V$. incana zmanjšali za 20-30\%, medtem ko se je pri vrsti $V$. austriaca ssp. teucrium zmanjšala le širina, dolžina pa se je povečala za $17 \%$. Analiza korelacije med podnebnimi dejavniki (temperatura zraka in količina padavin) in morfometričnimi parametri listov tekom rastne sezone je pokazala večji vpliv temperature zraka, in sicer z negativnim korelacijskim koeficientom $(\mathrm{r}=-0.55-0.66)$. Zaradi neugodnih rastnih razmer se je zmanjšal za 80-85\% razvoj podzemnih poganjkov, hkrati pa je za 1,5 krat prišlo do pospešenega razvejanja in povečane dolžine tankih koreninic. Vrste iz rodu Veronica, ki smo jih preučevali v ukrajinski stepi, uspešno razvijejo vse fenološke faze, ki jih zaznamuje širok nabor opaženih vegetativnih fenotipskih sprememb. 


\section{Introduction}

The problems related to climatic changes, environmental degradation and biodiversity loss have become global and continue to escalate under the heavy and ever-increasing pressure of the industrial society (Bramwell, 2008; Didukh, 2009). The dynamics of climatic changes in Ukraine is largely a replication of the relevant dynamics at a global scale. However, since the territory of Ukraine is located in the various geographical areas, these changes show themselves differently at the local level - there are deviations of parameters of the air temperature and precipitation amount from the climate normal for a certain latitude (Prykhodko, 2013).

These changes are manifested more significantly in the southern regions of the country, i.e. steppe zone, which occupies $40 \%$ of the area of Ukraine and is the most anthropogenically transformed one (Lykholat et al., 2019). Climatic changes in these regions are principally manifested in long-term droughts and lead to decrease in autoregulation of the plant aggregations and penetration of invasive alien species in the previously stable natural ecosystems, which limit the growth and spreading of the natural vegetation and reduce the cultivated plants' productivity (Yeremeiev, 2003; Shao et al., 2008). In response to the adverse changes of the environmental factors, the plants undergo restructuring which counteracts stresses, and adaptive reactions of an organism are realized at the various levels of organization. It means the change in metabolic processes, quantitative and qualitative anatomical clues and morphology of vegetative organs, cycles and biorhythms of development (Kordium et al., 2003; Koshkin, 2010; Grodzinskiy, 2013). The highest level of adaptation is the restructuring of rhythms of the plant development, which are especially evident in the long-term introduction of plants in conditions other than natural ones, and under the impact of climatic changes (Bullakh, 2005; Havens, 2008; Franklin, 2009; Hatfield et al., 2011; Sjöman et. al., 2015; Garofalo et al., 2019). Studying of adaptive features of the plant development will contribute to elaboration of the measures to prevent and eliminate the negative consequences for biodiversity in the face of climatic anomalies and rapid climatic changes (Anjum et al., 2011; Nedukha, 2015; Gray \& Brady, 2016).

Species of the genus Veronica L. in ornamental gardening are valued for the extraordinary beauty of blue, purple, pink, white flowers, long-lasted flowering, variety of shape and color of leaves, decorativeness throughout the growing season, simplicity of the growing conditions, resistance to diseases and pests (Didukh, 2000; Kaplan et al., 2007; Gusev, 2010). Unfortunately, they are not used at all in the greening of anthropogenic landscapes of the steppe zone of Ukraine because of lack of sufficient information on their ecological and biological features and adaptive capabilities in the arid conditions of growing. The lack of this data creates difficulties in solving of a number of practical problems, such as selection, seed raising, and cultivation techniques. Instead, according to the data of long-term observations of the species of the genus Veronica L. (V. armenica Boiss., $V$. austriaca L., $V$. incana L., V. prostrata L., V. spicata L.) in the conditions of the Kryvyi Rih Botanical Garden of the NAS of Ukraine, they can be used in the ornamental gardening in Kryvorizhzhya. All-round study of the biology of veronicas at the regional level will allow developing the ways to increase the level of vitality and resistance of plants and predict the expansion of phytodiversity towing to new fast-growing decorative species and cultivars tolerant to anthropogenic factors. Based on the above, the objective of this work is studying of ecological and biological features of the development of certain species of the genus Veronica L. in the conditions of the steppe zone of Ukraine (using the example of Kryvorizhzhya).

\section{Materials and methods}

\section{Study area}

The territory of the Kryvyi Rih agglomeration, or Kryvorizhzhya (Kryvyi Rih with the adjacent district centers), is $4100 \mathrm{~km}^{2}$. It is located in the steppe zone and is a part of the arid and very warm agro-climatic zone. Landscapes with the preserved natural flora occupy not more than $1-1.5 \%$ of the total area of the region, and they are fragmentary. Kryvyi Rih extends for over $100 \mathrm{~km}$ from north to south, with the largest mining and processing enterprises of Ukraine concentrated on its territory. Anthropogenic landscapes of the town (industrial, residential, agricultural, recreational and other ones) have a depleted biotic component which is obsolete in the sense of modern landscaping, and the plants in artificial phytocenoses are suppressed and do not fully display the decorative properties inherent to them (Denisik, 2005; Chipilyak et al., 2014). Over the last 30 years the average annual air temperature in Kryvorizhzhya region increased by $2{ }^{\circ} \mathrm{C}$ and its value is $10.0-11.5^{\circ} \mathrm{C}$ (in $2015-2020$ ) (Raspisaniye Pogodi Ltd., 2020; Lykholat et al., 2019). The average daily temperature in January-February increased from $-4.4--5.1{ }^{\circ} \mathrm{C}$ (1987) to $-0.9--2.1{ }^{\circ} \mathrm{C}(2020)$ and in July-September from $19.4-21.1{ }^{\circ} \mathrm{C}$ (1987) to $22.8-23.9^{\circ} \mathrm{C}(2020)$. Snow cover is not stable in winter. The annual precipitation is $350-450 \mathrm{~mm}$, with the deficient moisture balance recorded during summer months - only $100-150 \mathrm{~mm}$ of precipitation in the vegetation 
Table 1: Climatic indicators of Kryvorizhzhya for the periods 2011-2019.

Tabela 1: Podnebni kazalniki v kraju Kryvorizhzhya v obdobju 2011-2019.

\begin{tabular}{|c|c|c|c|c|c|c|c|c|c|c|c|c|c|c|}
\hline \multirow{2}{*}{ Indicators } & \multirow{2}{*}{ Years } & \multicolumn{12}{|c|}{ Months } & \multirow{2}{*}{$\begin{array}{l}\text { Average annual air } \\
\text { temperature, }{ }^{\circ} \mathrm{C}\end{array}$} \\
\hline & & I & II & III & IV & V & $\mathrm{VI}$ & VII & VIII & IX & $\mathrm{X}$ & XI & XII & \\
\hline \multirow{10}{*}{$\begin{array}{c}\text { Average } \\
\text { monthly air } \\
\text { temperature, } \\
{ }^{\circ} \mathrm{C}\end{array}$} & 2011 & -4.5 & -6.3 & 1.2 & 9.2 & 16.7 & 21.1 & 23.9 & 21.4 & 17.1 & 8.4 & 3.1 & 2.4 & 9.5 \\
\hline & 2012 & 3.7 & -9.5 & 0.6 & 14.7 & 20.1 & 22.7 & 25.5 & 24.8 & 22.7 & 12.6 & 3.0 & -3.1 & 10.9 \\
\hline & 2013 & -1.9 & 0.8 & 1.2 & 11.2 & 19.7 & 22.3 & 21.6 & 22.2 & 13.5 & 8.6 & 6.2 & -1.4 & 10.3 \\
\hline & 2014 & -3.6 & -1.8 & 6.7 & 10.4 & 17.7 & 19.3 & 23.3 & 23.3 & 17.0 & 8.2 & 2.0 & -1.8 & 10.0 \\
\hline & 2015 & -1.7 & -0.6 & 4.6 & 12.4 & 17.1 & 21.1 & 23.1 & 23.1 & 20.1 & 8.3 & 6.0 & 1.8 & 11.3 \\
\hline & 2016 & -4.7 & 2.7 & 5.4 & 13.1 & 16.1 & 21.6 & 23.4 & 23.4 & 16.3 & 7.4 & 2.6 & -1.9 & 10.5 \\
\hline & 2017 & -4.8 & -1.7 & 6.6 & 9.8 & 16.4 & 21.7 & 21.6 & 24.7 & 18.5 & 9.7 & 4.3 & 4.6 & 10.9 \\
\hline & 2018 & 1.7 & -1.5 & 0.4 & 14.0 & 19.5 & 22.4 & 23.5 & 24.8 & 19.1 & 12.3 & 1.3 & -1.3 & 11.4 \\
\hline & 2019 & -3.2 & 1.0 & 5.5 & 11.4 & 18.4 & 24.5 & 21.4 & 21.8 & 17.0 & 10.4 & 5.8 & 3.3 & 11.4 \\
\hline & & & & & & & & & & & & & & $\begin{array}{c}\text { Annual } \\
\text { precipitation, } \mathrm{mm}\end{array}$ \\
\hline \multirow{9}{*}{$\begin{array}{l}\text { Precipitation, } \\
\mathrm{mm}\end{array}$} & 2011 & 39.1 & 26.3 & 16.2 & 37.3 & 17.3 & 70.0 & 39.0 & 22.1 & 13.7 & 11.0 & 0.6 & 72.0 & 364.6 \\
\hline & 2012 & 80.5 & 23.8 & 21.2 & 28.9 & 49.1 & 30.4 & 85.7 & 83.8 & 55.7 & 100.0 & 19.2 & 56.6 & 634.9 \\
\hline & 2013 & 52.1 & 37.2 & 73.0 & 17.0 & 32.9 & 106.0 & 138.6 & 26.8 & 84.4 & 33.1 & 14.0 & 4.5 & 619.6 \\
\hline & 2014 & 31.3 & 10.2 & 15.2 & 136.9 & 84.3 & 52.4 & 59.2 & 49.1 & 51.8 & 30.0 & 9.8 & 34.3 & 561.5 \\
\hline & 2015 & 26.4 & 64.3 & 83.2 & 25.0 & 26.4 & 91.6 & 17.2 & 13.8 & 0.8 & 1.4 & 47.2 & 9.8 & 407.1 \\
\hline & 2016 & 32.4 & 7.0 & 31.0 & 39.0 & 80.4 & 56.4 & 10.0 & 34.2 & 15.6 & 68.8 & 42.4 & 13.8 & 431.0 \\
\hline & 2017 & 29.8 & 28.2 & 37.4 & 47.2 & 38.8 & 32.0 & 18.6 & 14.5 & 16.5 & 25.3 & 46.8 & 20.2 & 355.3 \\
\hline & 2018 & 54.2 & 22.4 & 95.0 & 12.4 & 24.0 & 19.8 & 51.8 & 0.0 & 15.0 & 3.2 & 26.6 & 26.0 & 347.5 \\
\hline & 2019 & 17.6 & 5.2 & 6.4 & 25.6 & 38.8 & 31.8 & 56.0 & 14.0 & 19.0 & 21.4 & 14.8 & 10.6 & 261.2 \\
\hline
\end{tabular}

period (Kazakov et al., 2005). Abnormally high air temperatures $\left(36.7-38.1^{\circ} \mathrm{C}\right)$ and frequent dry hot winds are recorded in summer. For the last 60 years, every 3-4 years in the decade are dry years, and severe droughts occur once every 5-10 years.

Our studies were carried out on the territory of the Kryvyi Rih Botanical Garden of the NAS of Ukraine (hereinafter referred to as KBG) (location data: $48^{\circ} 10^{\prime} \mathrm{N}$, $\left.3^{\circ} 40^{\prime} \mathrm{E}\right)$. Natural and climatic conditions of the botanical garden are characterized by common indicators for the steppe zone (Table 1), which limit the plant growth. The soil on the experimental plot is ordinary, mediumwashed, heavy loam chernozem.

\section{Studied species}

The objects of study were plants $V$. austriaca ssp. teucrium L. V. incana L. and V. prostrata L. (Figure 1), for which the introduction studies have been carried out in the Kryvyi Rih Botanical Garden of the NAS of Ukraine.

The genus Veronica belongs to the family Plantaginaceae Juss. 75 species of 300 known in the world grow in Ukraine. The studied samples of $V$. austriaca ssp. teucrium L., $V$. incana L. and $V$. prostrata L. by geographical zoning are natives to the Holarctic kingdom from the Circumboreal, Iranian-Turanian and East Asian regions (Takhtadzhyan, 1978). By the life form, they are herbaceous non-rosette polycarpous plants, by ecomorph - hemicryptophytes, xeromesophytes, and heliophytes (Raunkiaer, 1934).
V. austriaca ssp. teucrium L. occurs in the natural habitats in Western Europe (Germany, Austria, Hungary, Czech Republic, Slovakia, Poland, Romania), in Ukraine in the heads of Styr, Horyn and Prut rivers (Kaplan et al., 2007; Kuzemko, 2018). It grows in forest steppe, on mountain meadows, stony places and forest edges mainly on sandy soils (Korotchenko et al., 2009). It has the erect hairy stem of 30-70 cm tall. This species features bright-green sessile opposite leaves, which are ovate, with fine teeth, rounded base, pointed tip, and pubescence (Bubenchikova \& Kondratova, 2010). The species form a branched rhizome with short internodes and many thin lateral and additional roots. Flowers are of blue-violet color, $1-1.5 \mathrm{~cm}$ in diameter (Nestrogayeva, 2011).

$V$. incana $\mathrm{L}$. is common in the natural habitats of Europe and Asia. In Ukraine it is found in Transcarpathia and Polissia regions, less often in Crimea and Forest steppe. It grows on rocky slopes and in pine forests on sands (Krasnov et al., 2009). This species is characterized by silvery-gray oppositely arranged leaves with dense soft pubescence. In the lower part of the plant, they are assembled at the base into short shoots on the long $(3.5-4 \mathrm{~cm})$ leafstalks having the elongated shape. Leaves on generative shoots of 35-50 high are sessile, lance-linear, and acute. The rhizome is branched, ascending and woody, with numerous cord-like additional roots; on the internodes in the axils of buds the young plants with fibrous assemblage of rootlets are formed. The flowers are of dark blue color, $0.5-1.0 \mathrm{~cm}$ in diameter. 
The natural habitat of $V$. prostrata L. covers Turkey and almost all the territory of Europe. In Ukraine, this species is found on the forest edges, glades, shrubs, and meadows (Shvets, 2013). The species has numerous shoots

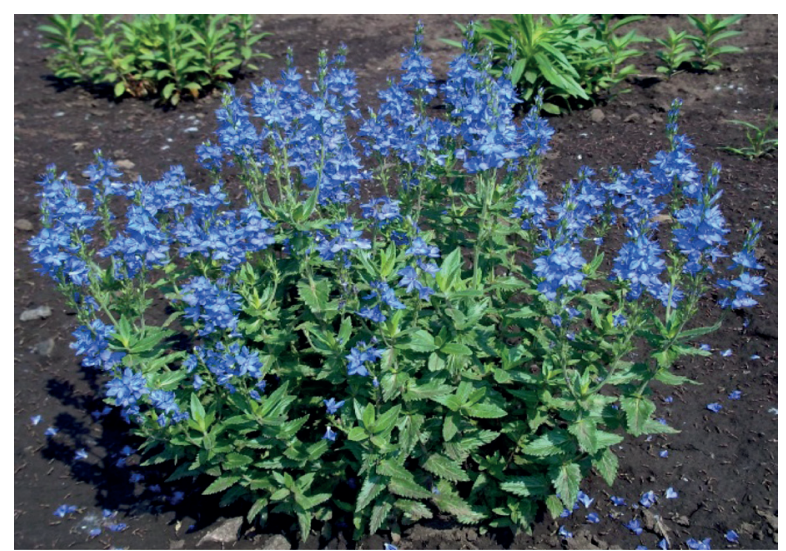

V. austriaca ssp. teucrium L.

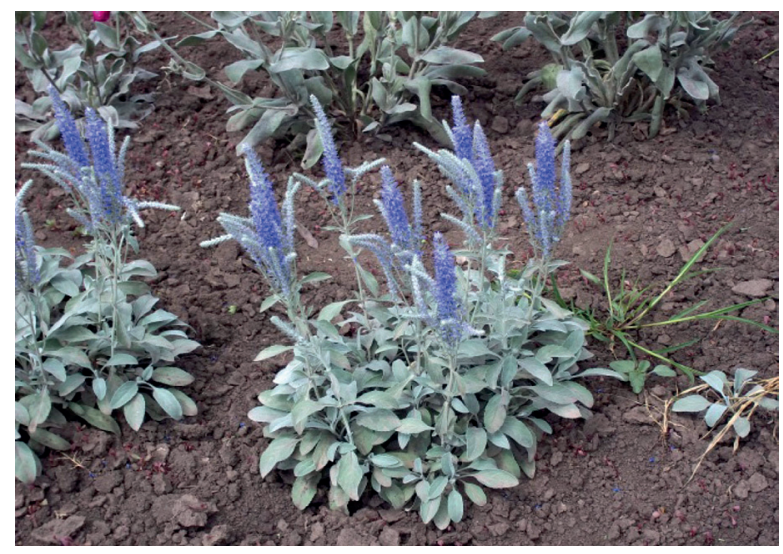

V. incana $\mathrm{L}$.

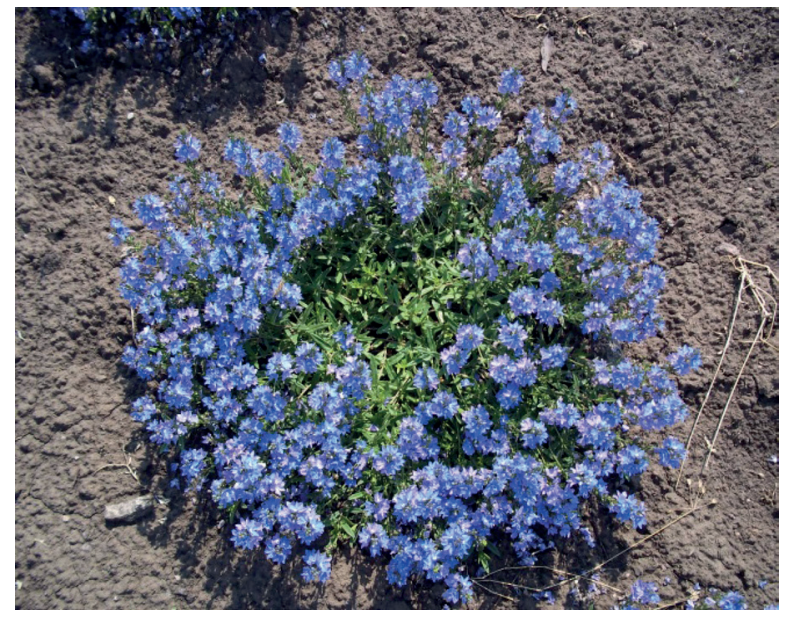

V. prostrata $\mathrm{L}$.

Figure 1: Species of studied veronicas in the Kryvyi Rih Botanical Garden of the NAS of Ukraine.

Slika 1: Vrste preučevanih jetičnikov v Botaničnem vrtu Narodne akademije znanosti Ukrajine Kryvyi Rih. of $10-15 \mathrm{~cm}$ tall of grayish-green color from the short uniform pubescence: procumbent vegetative shoots, and ascending generative shoots. Dark-green leaves are oppositely arranged: lower leaves are sessile, narrow-lanceolate; upper leaves are lance-linear, narrowed into very short leafstalk, with blunt tips, often with edges curved to the lower side, diffusely pubescent (Bubenchikova $\&$ Kondratova, 2010). Rhizome is of plagiotropic, creeping, woody, cord-like type, rooted in nodes, where the vegetative and generative shoots are developed later. Many thin additional and lateral roots penetrate to the depth of $10-18 \mathrm{~cm}$. Flowers are of blue-purple color, $0.8 \mathrm{~cm}$ in diameter.

\section{Phenological description}

One of the basic methods of research of the introduced plants is the comparative study of the rhythms of their seasonal development by visual assessment of the seasonal changes' manifestations, which allows establishing the time of different phases of development and assessing the stability, productivity and decorativeness of plants. Study of seasonal changes in the development during the age dynamics of growth of perennials allows determining their reactions to temperature changes and hydrological regime of the area of introduction (Havens, 2008; Hatfield et al., 2011; Sjöman et al., 2015). Phenological studies were conducted annually on 25 individuals of each species $(n=25)$, separately growing in the soil (ordinary chernozem) in one place during 10 years (2011-2020) with the natural water availability (see Table 1). For this, we used the unified technique of phenological observations in botanical gardens (Aleksandrova et al., 1975). For the comprehensive assessment of the seasonal development of plants, quantitative indicators were recorded on each phenological phase, as determined by visual calculation. The following phenological phases were recorded: $\mathrm{V}_{1}$ - beginning of vegetation (regrowth of the aerial part in more than $50 \%$ of experimental plants), $V_{2}$ - completion of regrowth of the aerial part in $100 \%$ of experimental plants, $B_{1}$ - formation of uncolored flower buds in more than $50 \%$ of experimental plants, $\mathrm{Fl}_{1}$ - beginning of flowering in more than $50 \%$ of experimental plants), $\mathrm{Fr}_{2}$ - fruitification (fruit formation and ripening in more than $50 \%$ of experimental plants), $\mathrm{V}_{3}$ - end of vegetation (die-away of $50 \%$ of the aerial part in more than $50 \%$ of experimental plants).

\section{Morphological descriptions}

Morphological characteristics of the leaf were determined by the generally accepted classification (Didukh, 2000), which involves study of the leaf shape, length, width and area of the leaf blade, parting of the edge of the leaf 
Table 2: Characteristics of meteorological conditions in 2020 (according to data of the meteorological station of KBG of the NAS of Ukraine, Kryvyi Rih).

Tabela 2: Značilnosti meteoroloških razmer v letu 2020 (glede na podatke meteorološke postaje KBG Narodne akademije znanosti Ukrajine, Kryvyi Rih).

\begin{tabular}{|l|ccc|c|}
\hline \multirow{2}{*}{ Month } & \multicolumn{3}{|c|}{$\begin{array}{c}\text { Air temperature, }{ }^{\circ} \mathrm{C} \\
\text { 2020/long-term data } \\
\text { max }\end{array}$} & $\begin{array}{c}\text { Average monthly precipitation, mm } \\
2020 / \\
\text { long-term data }\end{array}$ \\
\hline January & $-6.7 /-7.0$ & $7.3 /-2.0$ & $0.9 /-5.0$ & $6.4 / 40.0$ \\
February & $-11.6 /-6.0$ & $14.1 / 0.0$ & $2.1 /-3.6$ & $31.2 / 32.0$ \\
March & $-4.9 /-1.0$ & $21.6 / 4.0$ & $7.8 / 1.3$ & $11.8 / 28.0$ \\
April & $-3.4 / 5.0$ & $22.7 / 13.0$ & $10.1 / 9.5$ & $4.6 / 41.0$ \\
May & $4.7 / 10.0$ & $25.7 / 21.0$ & $14.4 / 15.9$ & $35.8 / 42.0$ \\
June & $7.4 / 13.0$ & $34.6 / 24.0$ & $22.9 / 19.5$ & $26.2 / 64.0$ \\
July & $12.2 / 15.0$ & $38.2 / 26.0$ & $23.9 / 21.1$ & $9.0 / 42.0$ \\
August & $10.2 / 14.0$ & $35.7 / 25.0$ & $22.8 / 20.5$ & $10.7 / 31.0$ \\
September & $12.8 /-3.7$ & $29.5 / 20.0$ & $26.7 / 15.6$ & 2.0 \\
\hline
\end{tabular}

Note: 2020 year indicators are given according to data of the meteorological station of KBG of the NAS of Ukraine, Kryvyi Rih; long-term average indicators of climatic conditions are taken from data of Lozovatka meteorological station, Kryvyi Rih.

blade etc. Investigation of morphostructural changes of assimilation organs during the seasonal ontogenetic development was carried out in 2020, when rather complex meteorological conditions of growing were observed (Table 2). In our case, watering was not carried out during seasonal studies, since we should find out the formation of the vegetative sphere of plants under the action of arid climatic conditions typical of our region.

In total, 5 individuals of each species of veronicas were studied. They were grown in the soil (ordinary chernozem) in one place during the last 5 years with the natural water availability. Leaves for the study were selected in three stages: phase of formation of uncolored flower buds (15.05.2020) taken as a control; phase of beginning of flowering (5.06.2020); and phase of fruit ripening (5.08.2020). From each unit at each stage, 25 leaves were selected from the middle part of the annual shoot. The sample size (n) for each species was 125 leaves at each stage. Area of the leaf was determined by the imprint method (Solomko et al., 2011) and calculated by the formula:

$$
\mathrm{S}=\mathrm{a} \cdot \mathrm{C} / \mathrm{b},
$$

where $S$ - area of the leaf; a - weight of the paper cut to the shape of the leaf, mg; $\mathrm{C}-$ of $100 \mathrm{~cm}^{2} ; \mathrm{b}$ - weight of a $100 \mathrm{~cm}^{2}$ of paper, $\mathrm{mg}$.

On paper of a certain density, we indicated the shape of the sheet (we circled the sheet along the contour). This complex figure was cut out of a sheet of paper and weighed on an analytical scale. From the same paper we cut out and weighed a square with the area of $10 \times 10 \mathrm{~cm}$ $\left(100 \mathrm{~cm}^{2}\right)$. The results were substituted into the calculation formula.
The morphological structure of the assemblage of rootlets was studied in 5-year-old equivalent individuals of each species $(n=10)$ with the natural water availability at the stages of development stated below: in late May (completion of formation of the surface vegetative part) and in early October (completion of vegetative development of plants). At each stage of the study, the sample size (n) for each species was 150 lateral roots and 50 rhizomes. The length of lateral roots on the main root, intensity of branching of lateral roots of the II order (secondary roots on lateral roots) and lateral roots of the III order (secondary roots on lateral roots of the II order) (Esau, 1980) was determined. The above roots in the general root system perform the function of absorption, nutrition and reproduction (Fedorov et al., 1962). Because almost 60\% of the roots on chernozem soils in the steppe zone are located at the depth of $15-20 \mathrm{~cm}$, the structure and seasonal changes of the root system in the soil profile to the depth of $30 \mathrm{~cm}$ were evaluated (Voitiuk et al., 1998).

\section{Data analysis}

Statistical data processing and degree of dependence of the studied parameters (correlation) were performed by the parametric statistics methods according to Yegorshyn \& Lisovyi (2005) and Prylutskyi et al. (2017). Statistical significance was set at $\mathrm{p}<0.05$ taking into account the variance and Student's criterion. In order to determine the degree of influence of the factors of the environment where the plants develop, the correlative analysis of the dependence of parameters of the leaf (length, width, 
area of the leaf) on average monthly air temperature and precipitation was carried out (Franklin, 2009). Dependence of morphological characteristics of plants on the climatic variables was calculated with the use of the Pearson correlation coefficient $(\mathrm{r})$ and correlation error $\left(\mathrm{m}_{\mathrm{r}}\right)$ at $p \leq 0.05$, where $0.2<\mathrm{r} \leq 0.5$ indicated the weak correlation, $0.5<\mathrm{r} \leq 0.7$ medium correlation, and $0.7<\mathrm{r} \leq 0.9$ strong correlation.

\section{Results}

Analysis of the obtained data confirmed the changes in the rhythms of development of the studied species in the conditions of Kryvorizhzhya. So, if the beginning of vegetation of $V$. prostrata and $V$. incana in 2011-2015 fell on the late March (March 19-23), during the last 5 years it was in the first half of March (March 8-14) (Figure 2, 3). In contrast to these species $V$. austriaca ssp. teucrium (Figure 4) for 10 years of observations began vegetation invariably in late March (March 20-26). During the last 5 years (2016-2020), vegetation was completed by species in early December, which led to increase in the growing season by 15 days in $V$. austriaca ssp. teucrium (Figure 4) and by 20 and 25 days in $V$. prostrata and $V$. incana, respectively (Figure 2, 3). Taking into account such changes, duration of the vegetation period of veronicas in the last 5 years is $245-255$ days, whereas in 2011-2016 this figure did not exceed 234 days.

Veronicas begin to bloom, as 10 years ago, in the appropriate time for each species: $V$. prostrata and $V$. austriaca ssp. teucrium in mid-May, and $V$. incana in late May and early June. The longest flowering period is featured by $V$. incana (32-37 days), and the shortest by $V$. austriaca ssp. teucrium (14-16 days). However, according to the average five-year indicators, only $V$. prostrata increased the duration of flowering by almost 10 days. For example, whereas in 2011-2015 the species bloomed for 17.2 \pm 1.9 days, then in 2016-2020 for 26.4 \pm 3.6 days (Figure 5). Regarding the other two species, no significant changes in flowering duration were observed: in $V$. incana $32.6 \pm 5.8$ (2011-2015) and 35.2 \pm 6.8 (2016-2020), in V. austriaca ssp. teucrium $14.2 \pm 5.8$ and $16.4 \pm 4.6$ days respectively. Fruitification of the studied species was regular; time of occurrence of this phase did not differ significantly.

Studies of development of the aerial vegetative organs of veronicas prove that the leaf blade area in species $V$. incana and $V$. austriaca ssp. teucrium increased in the flowering stage relative to the time of bud formation by $25 \%$ and $53 \%$, respectively, owing to increase of length of the leaf 1.3 and 1.5 times (Figure 6).

Instead, in $V$. prostrata at this stage of research, the length and area of the leaf reduced by $12-13 \%$. It should

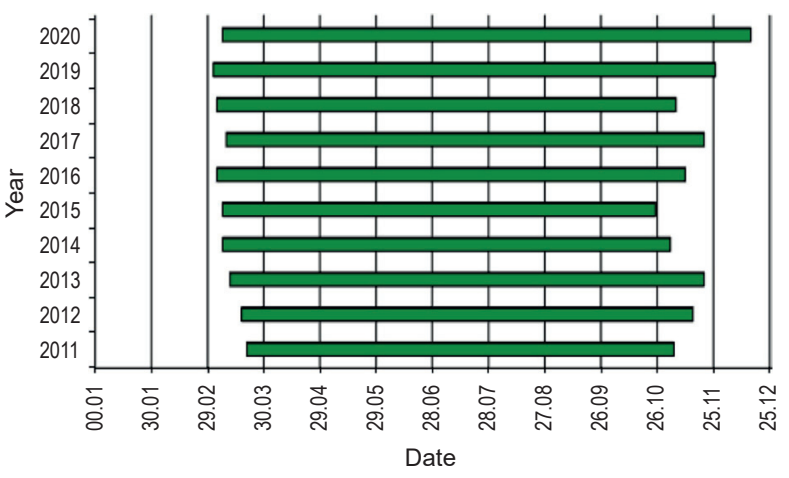

Figure 2: Duration of vegetative period of Veronica prostrata L. in the conditions of the Kryvyi Rih Botanical Garden of the NAS of Ukraine in 2011-2020.

Slika 2: Dolžina trajanja vegetativne faze vrste Veronica prostrata L. v razmerah Botaničnega vrta Narodne akademije znanosti Ukrajine, Kryvyi Rih v obdobju 2011-2020.

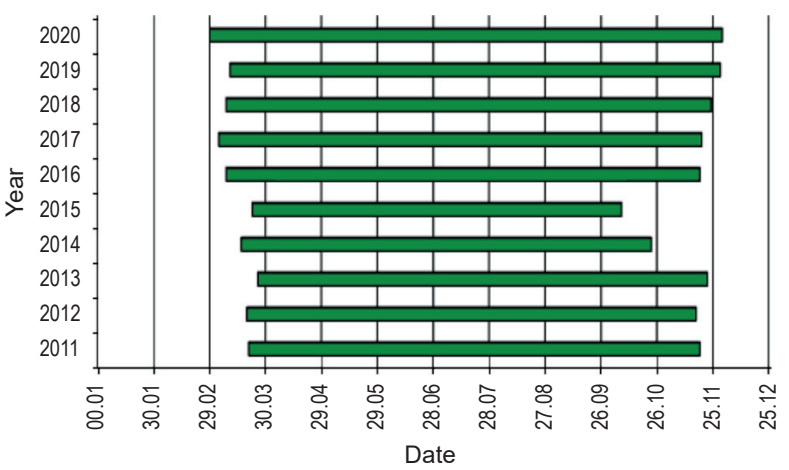

Figure 3: Duration of vegetative period of Veronica incana L. in the conditions of the Kryvyi Rih Botanical Garden of the NAS of Ukraine in 2011-2020.

Slika 3: Dolžina trajanja vegetativne faze vrste Veronica incana L. v razmerah Botaničnega vrta Narodne akademije znanosti Ukrajine, Kryvyi Rih v obdobju 2011-2020.

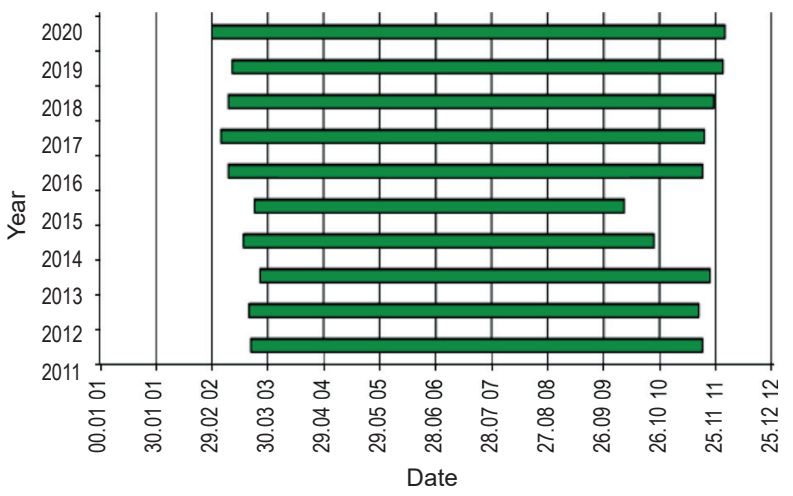

Figure 4: Duration of vegetative period of $V$. austriaca ssp. teucrium L. in the conditions of the Kryvyi Rih Botanical Garden of the NAS of Ukraine in 2011-2020.

Slika 4: Dolžina trajanja vegetativne faze vrst $V$. austriaca ssp.

teucrium L v razmerah Botaničnega vrta Narodne akademije znanosti Ukrajine, Kryvyi Rih v obdobju 2011-2020. 


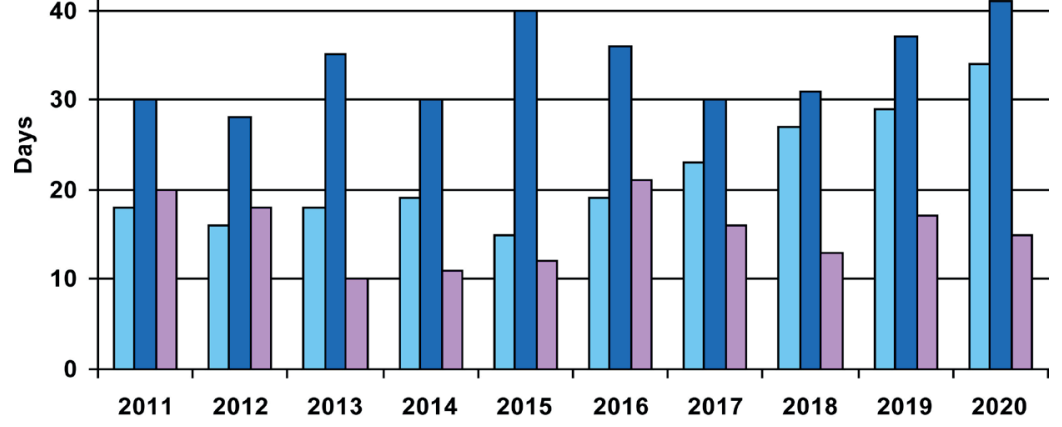

$\square$ Veronica prostrata $\square$ Veronica incana $\square$ Veronica austriaca ssp. teucrium
Figure 5: Duration of flowering of certain species of the genus Veronica L. in the conditions of the Kryvyi Rih Botanical Garden of the NAS of Ukraine in 2011-2020.

Slika 5: Dolžina trajanja faze cvetenja za nekatere vrste iz rodu Veronica L. v razmerah Botaničnega vrta Narodne akademije znanosti Ukrajine, Kryvyi Rih v obdobju 2011-2020.
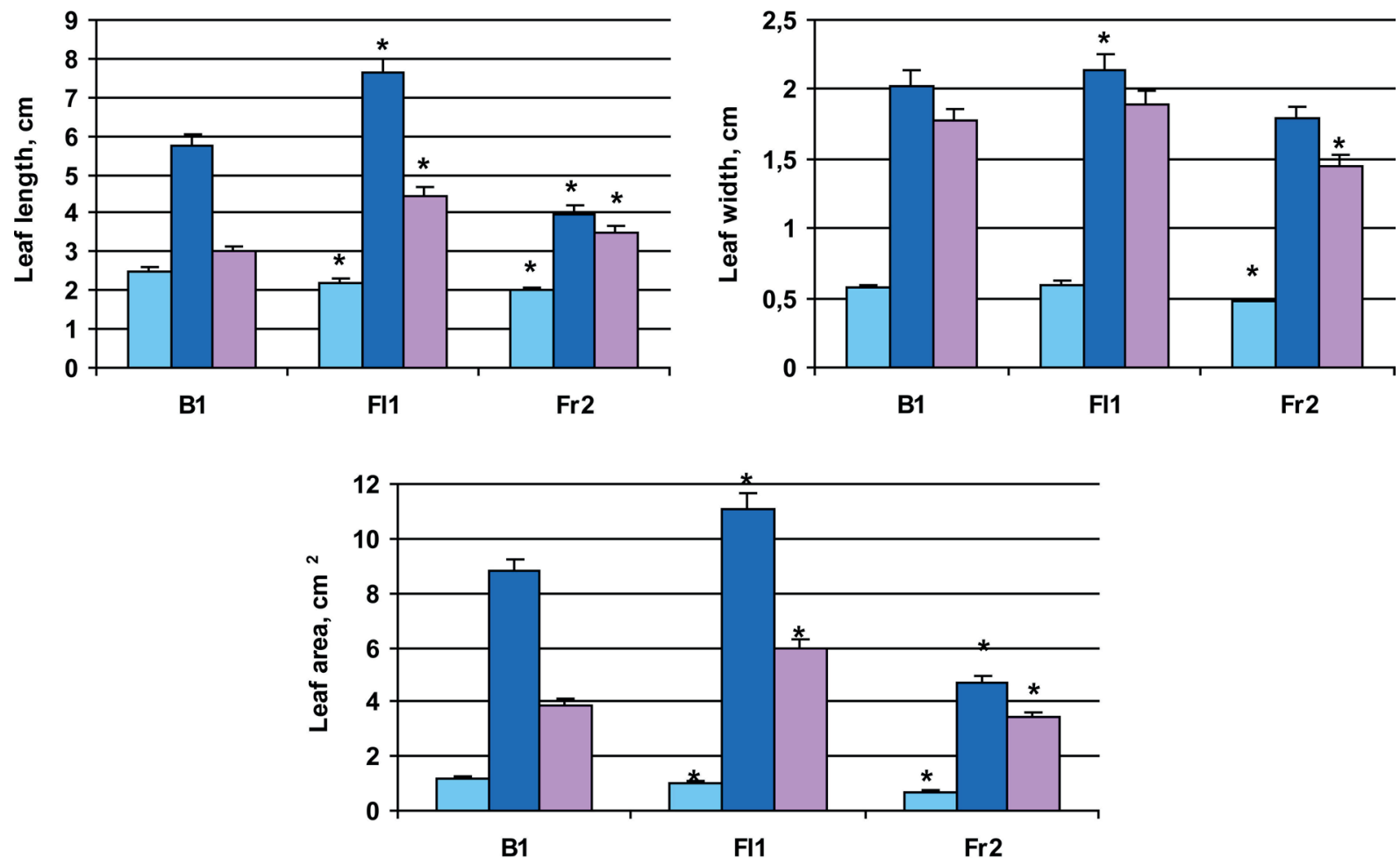

$\square$ V. prostrata

$\square V$. incana

$\square$ V. austriaca ssp. teucrium

Figure 6: Morphometric indicators of growth and development of leaves of certain species of the genus Veronica L. during their morphogenesis in the Kryvyi Rih Botanical Garden of the NAS of Ukraine ( $\mathrm{B}_{1}$ - phase of formation of uncolored flower buds (15.05.2020); $\mathrm{Fl}_{1}$ - phase of beginning of flowering (5.06.2020); $\mathrm{Fr}_{2}$ - phase of fruit ripening (5.08.2020); ${ }^{*}$ - statistically significant difference with control by Student's criterion at $\left.p \leq 0.05\right)$. Slika 6: Morfometrični kazalniki rasti in razvoja listov nekaterih vrst iz rodu Veronica L. tekom morfogeneze v Botaničnem vrtu Narodne akademije znanosti Ukrajine, Kryvyi Rih ( $\mathrm{B}_{1}$ - faza nastajanja neobarvanih cvetnih popkov (15. 05. 2020); $\mathrm{Fl}_{1}$ - faza začetka cvetenja (5. 06. 2020);

$\mathrm{Fr}_{2}$ - faza dozorevanja plodov (5. 08. 2020); * - statistično značilna razlika v primerjavi s kontrolo glede na Studentov t-test pri $\left.p \leq 0.05\right)$.

be noted that for this species the decrease of up to $80 \%$ of the linear parameters of the leaf and 1.7 times its area were characteristic in the phase of fruit ripening. In $V$. incana the reduction of $12 \%$ in width and $31 \%$ in length of the leaf in the phase of fruit ripening was recorded as well; it caused the decrease in the total area of the leaf blade 1.8 times. As distinct from the other studied species of veronicas, in $V$. austriaca ssp. teucrium the area of the leaf blade during the vegetation did not change significantly, but the leaf took more elongated shape due to increase of $16.7 \%$ in length and decrease of $18.2 \%$ in width. In addition, there are more pronounced dissections of the leaf edge, and their number is increasing on both sides. 
Table 3: Dependence of morphometric parameters of leaves of certain species of the genus Veronica L. on air temperature and amount of precipitation per month in the conditions of the Kryvyi Rih Botanical Garden of the NAS of Ukraine in 2020 $\left(\mathrm{B}_{1}\right.$ - phase of formation of uncolored flower buds (15.05.2020); $\mathrm{Fl}_{1}$ - phase of beginning of flowering (5.06.2020); $\mathrm{Fr}_{2}$ - phase of beginning of fruit ripening (5. 08. 2020), $\mathrm{r}-$ correlation coefficient, $\mathrm{m}_{\mathrm{r}}-$ correlation error at $p \leq 0.05$.).

Tabela 3: Odvisnost morfometričnih parametrov listov nekaterih vrst iz rodu Veronica L. od temperature zraka in količine padavin na mesec v razmerah Botaničnega vrta Narodne akademije znanosti Ukrajine, Kryvyi Rih v letu 2020 ( $B_{1}$ - faza nastajanja neobarvanih cvetnih popkov (15.05.2020); $\mathrm{Fl}_{1}$ - faza začetka cvetenja (5. 06. 2020); $\mathrm{Fr}_{2}$ - faza dozorevanja plodov (5.08.2020), $\mathrm{r}-$ korelacijski koeficient, $\mathrm{m}_{\mathrm{r}}-$ korelacijska napaka, pri $\left.p \leq 0.05.\right)$.

\begin{tabular}{|c|c|c|c|c|c|c|}
\hline \multirow{2}{*}{$\begin{array}{c}\text { Phase pf } \\
\text { development }\end{array}$} & \multicolumn{2}{|c|}{$\begin{array}{c}\text { Leaf length } \\
r \pm m_{r}\end{array}$} & \multicolumn{2}{|c|}{$\begin{array}{l}\text { Leaf width } \\
\quad \mathrm{r} \pm \mathrm{m}_{\mathrm{r}}\end{array}$} & \multicolumn{2}{|c|}{$\begin{array}{c}\text { Leaf area } \\
\mathrm{r} \pm \mathrm{m}_{\mathrm{r}}\end{array}$} \\
\hline & $\begin{array}{c}\text { Air temperature } \\
{\left[{ }^{\circ} \mathrm{C}\right]} \\
\end{array}$ & $\begin{array}{l}\text { Precipitation } \\
\text { per month }\end{array}$ & $\begin{array}{c}\text { Air temperature } \\
{\left[{ }^{\circ} \mathrm{C}\right]} \\
\end{array}$ & $\begin{array}{l}\text { Precipitation per } \\
\text { month }\end{array}$ & $\begin{array}{c}\text { Air temperature } \\
{\left[{ }^{\circ} \mathrm{C}\right]} \\
\end{array}$ & $\begin{array}{c}\text { Precipitation } \\
\text { per month } \\
\end{array}$ \\
\hline \multicolumn{7}{|c|}{ Veronica incana } \\
\hline $\mathrm{B}_{1}$ & $-0.27 \pm 0.01$ & $0.31 \pm 0.01$ & $-0.41 \pm 0.02$ & $0.34 \pm 0.01$ & $-0.40 \pm 0.01$ & $0.34 \pm 0.02$ \\
\hline $\mathrm{Fl}_{1}$ & $-0.42 \pm 0.02$ & $0.33 \pm 0.02$ & $-0.35 \pm 0.03$ & $0.44 \pm 0.02$ & $-0.38 \pm 0.02$ & $0.42 \pm 0.01$ \\
\hline $\mathrm{Fr}_{2}$ & $-0.55 \pm 0.01$ & $0.49 \pm 0.02$ & $-0.66 \pm 0.01$ & $0.57 \pm 0.02$ & $-0.64 \pm 0.02$ & $0.55 \pm 0.03$ \\
\hline \multicolumn{7}{|c|}{ Veronica prostrata } \\
\hline $\mathrm{B}_{1}$ & $-0.49 \pm 0.03$ & $0.35 \pm 0.02$ & $-0.41 \pm 0.04$ & $0.24 \pm 0.02$ & $-0.44 \pm 0.02$ & $0.41 \pm 0.02$ \\
\hline $\mathrm{Fl}_{1}$ & $-0.50 \pm 0.02$ & $0.22 \pm 0.01$ & $-0.54 \pm 0.03$ & $0.38 \pm 0.02$ & $-0.55 \pm 0.03$ & $0.30 \pm 0.01$ \\
\hline $\mathrm{Fr}_{2}$ & $-0.51 \pm 0.01$ & $0.27 \pm 0.02$ & $-0.63 \pm 0.04$ & $0.29 \pm 0.02$ & $-0.61 \pm 0.02$ & $0.42 \pm 0.03$ \\
\hline \multicolumn{7}{|c|}{ Veronica austriaca ssp. teucrium } \\
\hline $\mathrm{B}_{1}$ & $-0.48 \pm 0.24$ & $0.28 \pm 0.02$ & $-0.46 \pm 0.02$ & $0.30 \pm 0.01$ & $-0.45 \pm 0.02$ & $0.32 \pm 0.02$ \\
\hline $\mathrm{Fl}_{1}$ & $-0.45 \pm 0.01$ & $0.31 \pm 0.01$ & $-0.55 \pm 0.01$ & $0.30 \pm 0.02$ & $-0.54 \pm 0.02$ & $0.35 \pm 0.03$ \\
\hline $\mathrm{Fr}_{2}$ & $-0.54 \pm 0.01$ & $0.41 \pm 0.02$ & $-0.65 \pm 0.01$ & $0.36 \pm 0.03$ & $-0.61 \pm 0.02$ & $0.40 \pm 0.02$ \\
\hline
\end{tabular}

Calculation of correlation coefficients showed the inverse correlation between air temperature and leaf size. Moreover, the higher the temperature, the stronger the correlation, which is confirmed by the highest coefficients in August, from $r=-0.51$ to $r=-0.66$ (Table 3).

However, whereas for $V$. prostrata and $V$. austriaca ssp. teucrium the average degree of association ( $\mathrm{r}=-0.54-$ -0.55) was recorded in June, for $V$. incana it was recorded in August. Instead, the morphometric indicators of leaf development of the studied species showed the weak dependence on the average monthly precipitation, as confirmed by the positive correlations in the range of $r=+0.22-+0.57$ (see table 3 ). However, it should be noted that for $V$. incana in the fruit ripening phase, medium correlation was observed $(\mathrm{r}=+0.52-+0.57)$.

Table 4: Certain indicators of development of the assemblage of rootlets of species of the genus Veronica L. during seasonal ontogenetic development in the conditions of Kryvorizhzhya $\left(\mathrm{V}_{2}\right.$ - completion of formation of the surface vegetative part (10.06.20); $\mathrm{V}_{3}$ - completion of vegetative development of plants (20.10.20), * - statistically significant difference with control by Student's criterion at $p \leq 0.05$.

Tabela 4: Nekateri kazalniki razvoja koreninskega spleta nekaterih vrst iz rodu Veronica L tekom sezonskega ontogenetskega razvoja v razmerah v Kryvorizhzhyi $\left(V_{2}-\right.$ zaključen razvoj nadzemnih vegetativnih delov (10.06.20); $V_{3}-$ zaključena sezona vegetativne faze $(20.10 .20), *$ - statistično značilna razlika v primerjavi s kontrolo glede na Studentov t-test pri $p \leq 0.05$.

\begin{tabular}{|c|c|c|c|c|c|}
\hline Phase & $\begin{array}{c}\text { Length of lateral } \\
\text { roots on the main } \\
\text { root, } \mathrm{cm}\end{array}$ & $\begin{array}{l}\text { Quantity of secondary } \\
\text { roots on the lateral root }\end{array}$ & $\begin{array}{l}\text { Quantity of lateral roots } \\
\text { of the secondary root }\end{array}$ & $\begin{array}{l}\text { Rhizome length, } \\
\qquad \mathrm{cm}\end{array}$ & $\begin{array}{l}\text { Diameter of the } \\
\text { assemblage of } \\
\text { rootlets, } \mathrm{cm}\end{array}$ \\
\hline \multicolumn{6}{|c|}{ V. austriaca ssp. teucrium } \\
\hline $\mathrm{V}_{2}$ & $13.4 \pm 1.7$ & $32.8 \pm 7.3$ & $6.8 \pm 2.6$ & $7.3 \pm 3.5$ & $23.4 \pm 2.9$ \\
\hline $\mathrm{V}_{3}$ & $18.3 \pm 2.7^{*}$ & $45.6 \pm 2.9^{*}$ & $3.8 \pm 1.2^{*}$ & $1.6 \pm 0.9^{*}$ & $17.5 \pm 3.2^{*}$ \\
\hline \multicolumn{6}{|c|}{ V. incana } \\
\hline $\mathrm{V}_{2}$ & $20.3 \pm 4.3$ & $52.8 \pm 7.4$ & $1.3 \pm 0.7$ & $5.2 \pm 1.8$ & $33.4 \pm 2.3$ \\
\hline $\mathrm{V}_{3}$ & $27.1 \pm 8.6$ & $43.8 \pm 4.9$ & $1.1 \pm 0.8$ & $10.6 \pm 5.2^{*}$ & $31.2 \pm 3.1$ \\
\hline \multicolumn{6}{|c|}{ V. prostrata } \\
\hline $\mathrm{V}_{2}$ & $12.5 \pm 1.9$ & $37.1 \pm 3.2$ & $1.6 \pm 0.4$ & $13.4 \pm 1.8$ & $17.7 \pm 2.1$ \\
\hline $\mathrm{V}_{3}$ & $23.4 \pm 7.5^{*}$ & $54.8 \pm 2.7^{*}$ & $1.4 \pm 0.7$ & $4.6 \pm 1.1^{*}$ & $16.2 \pm 1.5$ \\
\hline
\end{tabular}


Study of the peculiarities of formation of the assemblage of rootletsof representatives of the genus Veronica conducted during the vegetation season in 2020, showed that $V$. austriaca ssp. teucrium, $V$. incana and $V$. prostrata formed rhizomes of various degree of branching with numerous thin roots performing the suction functions. Thickened vegetative underground shoots form a certain number of ascending aboveground shoots. Analysis of the obtained quantitative indicators of the development of the assemblage of rootlets in veronica species indicates the species-specificity of its formation. For example, in October, when the vegetative development of plants completed, in $V$. austriaca ssp. teucrium compared to May (phase of completion of the formation of the surface vegetative part) the length of suction roots of the I order increased by $37 \%$, whereas intensity of their branching featured growth 1.4 times. At the same time, length of rhizomes decreased by $78 \%$, which led to the denser arrangement of roots and, consequently, reduction of the total diameter of the plant's root system (Table 4).

Similar root rearrangements were characteristic of $V$. prostrata as well: length of suction roots of the I order increased by $87 \%$, and intensity of their branching was 1.5 times higher, whereas the length of rhizomes decreased by $66 \%$. In V. incana no significant changes in the structure of the assemblage of rootlets during the vegetation season were detected.

\section{Discussion}

All species have the appropriate potential and genetically determined properties of adaptation to specific natural and climatic conditions, and success of their adaptation depends on the variability of genetically determined variation of characters, which provides adaptation to new environmental conditions (Bubenchikova \& Kondratova, 2010; El-Sahhar et al., 2011; Bahuguna \& Jagadish, 2015; Marchyshyn et al., 2015). For example, study of species of the genus Veronica L. in the arid conditions shows that the formation of new life forms or shortening of the life cycle is typical for them (Hrytsyna, 2016; Wang et al., 2016). The species under study increased the vegetation period by $20-25$ days due to its earlier beginning and later ending in the conditions not characteristic of their natural area of distribution (i.e. the steppe zone of Ukraine). Instead, the development of the generative sphere (time of beginning, duration) showed no changes. This fact indicates certain conservatism of the species and low level of response to changes in the environmental conditions over the past 10 years.

Systemic mechanisms of plant adaptation to adverse environmental factors are associated with the modifications of leaves and roots, because they are the most flexible organs of plants, which reflect not only the ecological and climatic conditions in which this genotype has formed, but also the response of the organism to the changing living conditions (Wahid et al., 2007, Gorlacheva, 2010; Krokhmal, 2014). Area of the leaf and its linear dimensions, in combination with quantitative indicators of growth of the assemblage of rootlets, characterize the state of the plant under stress action of many factors and indicate the adaptive rearrangement characteristic for them in the area of introduction (De Micco \& Aronne, 2012; Bano et al., 2019). During the seasonal development under the influence of extreme climatic conditions of Kryvorizhzhya, we recorded quantitative fluctuations of morphometric parameters of the leaf - the leaf took more elongated shape due to increase in its length and decrease in the width, while the leaf blade area decreased or did not change significantly. The evidence was provided for existence of medium inverse correlation between the air temperature and size of assimilation organs and weak positive correlation between the precipitation amount and the width and area of leaves. Such phenotypic changes in the shape of the leaf indicate the presence of adaptive responses of the assimilation apparatus to lack of moisture and high temperatures, and help to reduce the negative effects of stressors (Gusev, 2010; Sjöman et al., 2015).

The crucial role in the increase of the productivity of the plant organism is given to the assemblage of rootlets, which is the first to be affected by water stress and is better adapted to changes in soil conditions and environmental factors (Zamski et al., 1983; Wahid et al., 2007). Peculiarities of development of veronicas' root system in edaphic conditions of Kryvorizhzhya (increase of air temperature, drought intensification and interaction thereof) include the increase of length and intensity of branching of lateral roots, which perform the function of nutrition and considerable shortening of length of rhizomes responsible for the function of reproduction. It has led to change of the spatial structure of the underground part of plants and, in our opinion, contributed to more efficient moisture absorption (Verslues et al., 2006).

We can attribute to species-specific peculiarities the significant conservatism of $V$. austriaca ssp. teucrium, which was manifested in slight changes of the rhythms of development over the past 10 years, but the species is characterized by the seasonal phenotypic variability of the vegetative organs morphological structure. In our opinion, in the future, conservatism in phenological development will hinder the adaptation of $V$. austriaca ssp. teucrium under climatic changes. We think it is due to the considerably narrower area of species (mountainous and forested areas in Europe) typical for it. Instead, $V$. 
prostrata in the conditions of the steppe zone of Ukraine is characterized by high flexibility: it is the considerable increase in the period of vegetation and flowering over the past 10 years and manifestation of signs of xeromorphism during seasonal development, such as decrease in leaf area because of small size of cells of its tissues (Leshcheniuk, 2020). The identified reactions, apparently, contributed to the regulation of gas exchange and transpiration as shown in studies (Wang et al., 2016; Bano et al., 2019) and provided the plant protection under the action of elevated air temperature, as indicated by inverse correlation coefficient above the average level.

\section{Conclusion}

The established peculiarities of development of species of the genus Veronica L. under the influence of excessive temperatures and lack of moisture in the conditions of the steppe zone of Ukraine indicate rather wide adaptive capabilities of such species. Taking into account the fact that they belong to the group of new and minor plant species and are still practically not used in the ornamental horticulture of Kryvorizhzhya, studies of their viability at different levels of organization (seasonal changes in morphological structure and long-term pheno-development of plants) contribute to the elaboration of techniques of their growing and reproduction in the conditions of extremely high temperatures and insufficient moisture level. It will enrich phytodiversity in general and expand the range of valuable highly ornamental species for the design of anthropogenic landscapes of the steppe zone of Ukraine.

Tetiana Chypyliak (D) https://orcid.org/0000-0003-2193-5350 Olha Zubrovska (D) https://orcid.org/0000-0002-4173-2457

\section{References}

Aleksandrova, M. S., Bulygin, N. Ye., Voroshilov, V. N., Karpisonova, R. A., Plotnikova, L. S., Frolova, L. A., \& Shkutko, N. V. (1975). Methods of phenological observations in the botanical gardens of the USSR. State Botanical Garden of the USSR Academy of Sciences. [in Russian]

Anjum, S. A., Xie, X.-Y., Wang, L.-C., Saleem, M. F., Man, Ch., \& Lei, W. (2011). Morphological, physiological and biochemical responses of plants to drought stress. African Journal of Agricultural Research, 6(9), 2026-2032. https://doi.org/10.5897/AJAR10.027

Bahuguna, R. N., \& Jagadish, K. S. V. (2015). Temperature regulation of plant phenological development. Environmental and Experimental Botany, 111, 83-90. https://doi.org/10.1016/j.envexpbot.2014.10.007

Bano, Ch., Amist, N., \& Singh, N. B. (2019). Morphological and Anatomical Modifications of Plants for Environmental Stresses. In A. Roychoudhury, \& D. Tripathi (Eds.), Molecular Plant Abiotic Stress: Biology and Biotechnology (pp. 29-45). John Wiley \& Sons. https://doi.org/10.1002/9781119463665.ch2
Bramwell, D. (2008, June 29-July 4). Plant adaptation and climate change [Conference presentation abstract]. 2nd World Scientific Congress Challenges in Botanical Research and Climate Change, Delft, The Netherlands.

Bubenchikova, V. N., \& Kondratova, Yu. A. (2010). Plants of the genus Veronica. GOU VPO KSMU Roszdrav. [in Russian]

Bulakh, P. E. (2005). Phenological criteria of stability in introduction of plants. Plant introduction, 4, 9-19. [in Russian with English summary]

Chipilyak, T. F., Mazura, M. Yu, Bereslavskaya, E. A., \& Leshcheniuk, E. N. (2014). Flower Design of Parks and Squares in Krivoy Rog: Status, Problems and Recommendations for Improvement. Scientific Bulletin of UNFU, 24(4), 164-169. [in Ukrainian with English summary]

De Micco, V., \& Aronne, G. (2012). Morpho-Anatomical Traits for Plant Adaptation to Drought. In R. Aroca (Eds.), Plant Responses to Drought Stress (pp. 37-61). Springer. https://doi.org/10.1007/978-3642-32653-0_2

Denisik, H. I. (2005). Kryvbas is a unique landfill for studying the industrial landscapes of Ukraine. Theoretical, regional, applied directions of development of anthropogenic geography and landscape science [Conference presentation abstract]. II International Science Conference, Kryvyi Rih, Ukraine. [in Ukrainian]

Didukh, Y. P. (Ed.). (2000). Ecoflora of Ukraine. Phytosociocenter. [in Ukrainian]

Didukh, Y. P. (2009). Ecological aspects of the global climate changes: reasons, consequences and actions. News of Ukrainian Academy of Sciences, 2, 34-44. [in Ukrainian with English summary]

El-Sahhar, K. F., Nassar, D. M., \& Farag, H. M. (2011). Morphological and Anatomical Studies of Santolina chamaecyparissus L. (Asteraceae). Anatomical Characteristics and Volatile Oil. Research Journal of Agriculture \& Biological Sciences, 7(6), 413-422.

Esau, K. (1980). Anatomy of seed plants (Book 2). Publishing house "Mir". [in Russian]

Fedorov, A .A., Kirpichnikov, M. E., \& Artyushenko, Z. T. (1962). Atlas of Descriptive Morphology of Higher Plants. Stem and root. Publishing house of the Academy of Sciences of the USSR. [in Russian]

Franklin, K. A. (2009). Light and temperature signal crosstalk in plant development. Current Opinion in Plant Biology, 12(1), 63-68. https:// doi.org/10.1016/j.pbi.2008.09.007

Garofalo, P., Ventrella, D., Kersebaum, K.C., Gobin, A., Trnka, M., Giglio, L., Dubrovský, M., \& Castellini, M. (2019). Water footprint of winter wheat under climate change: trends and uncertainties associated to the ensemble of crop models. Science of the Total Environment, 658, 1186-1208. https://doi.org/10.1016/j.scitotenv.2018.12.279

Gorlacheva, Z. S. (2010). Anatomic-morphological leaf structure of different Monarda $\times$ bybrida Hort. Models. Industrial botany, 10, 148-151. [in Russian]

Gray, S. B., \& Brady, S. M. (2016). Plant developmental responses to climate change. Developmental Biology, 419, 64-77. https://doi. org/10.1016/j.ydbio.2016.07.023

Grodzinsky, D. M. (2013). Adaptive strategy of plant physiological processes. Naukova Dumka. [in Ukrainian]

Gusev, N. F. (2010). Biological features and prospects for the use of plants of the genus Veronica L. (family Scrophulariaceae Juss.) of the Foreststeppe and Steppe Cis-Urals. [Abstract of thesis for the scientific degree of Candidate in Biological Sciences, Orenburg State Pedagogical University https://studfile.net/preview/8077794/page:2/ [in Russian]. 
Hatfield, J. L., Boote, K. J., Kimball, B. A., Ziska, L. H., Izaurralde, R. C., Ort, D., Thomson, A. M., \& Wolfe, D. (2011). Climate impacts on agriculture: implications for crop production. Agronomy Journal, 103(2), 351-370. https://doi.org/10.2134/agronj2010.0303.

Havens, K. H. (2008, June 29-July 4). Plant responses to climate change: phenology, adaptation, migration [Conference presentation abstract]. 2nd World Scientific Congress Challenges in Botanical Research and Climate Change, Delft, The Netherlands.

Hrytsyna, M. R. (2016). Structure life forms of the species of the family Plantaginaceae. Scientific Messenger of LNU of Veterinary Medicine and Biotechnologies. Series "Agricultural sciences", 18(2), 66-69. https:// doi.org/10.15421/nvlvet6715 [in Ukrainian with English summary]

Kaplan, A. R., Hasanoglu, A., \& Ince, I. A. (2007). Morphological, Anatomical and Palynological Properties of Some Turkish Veronica L. Species (Scrphulariaceae). International Journal of Botany, 3(1), 23-32. https://doi.org/10.3923/ijb.2007.23.32

Kazakov, V. L., Paranko, I. S., Smetana, M. G. Shypunova, V. O., Kotsyuruba, V. V., \& Kalinichenko, O. O. (2005). Natural geography of Kryvbas. KDPU. [In Ukrainian]

Kordium, E. L., Sytnik, K. M., Baranenko, V. V., Beliavskaia, N. A., \& Klimchuk, D. A. (2003). Cellular mechanisms of plant adaptation to the adverse effects of environmental factors in natural conditions. Naukova dumka. [in Russian]

Korotchenko, I. A., Mala, Yu. I., \& Fitsaylo, T. V. (2009). Syntaxonomy of steppe vegetation of the extreme North of Steppe of Right Bank Dnieper Region of the Ukraine. Biological Systems, 1(1), 73-84. [in Ukrainian with English summary]

Koshkin, E. I. (2010). Physiology of crop sustainability. Drofa. [in Russian]

Krasnov, V. P., Orlov, O. O., \& Vedmid', M. M. (2009). Atlas of indicator plants and types of forest vegetation conditions of Ukrainian Polissya: [monograph]. NOVOgrad. [in Ukrainian]

Krokhmal, I. I. (2014). Anatomical and physiological features of Campanula glomerata L. Chornomors'ki Botanical Journal, 10(2), 167-178. https://doi.org/10.14255/2308-9628/14.102/2 [in Ukrainian with English summary]

Kuzemko, A. A., Didukh, Ya. P., Onyshchenko, V. A., \& Sheffer Ya. (Eds.) (2018). National habitat catalogue of Ukraine. FOP Klimenko Yu.Ya. [in Ukrainian]

Leshcheniuk, E. N., \& Chipilyak, T. F. (2020). Morpho-anatomical adaptation of the leaves of certain Veronica species to arid conditions. Plant Introduction 87/88, 47-53. https://doi.org/10.46341/PI2020023

Lykholat, Y. V., Khromykh, N. O., Didur, O. O., Okovytyy, S. I., Matyukha, V. L., Savosko, V. M., \& Lykholat, T. Y. (2019). The current state of anthropogenic transformation of the steppe Dnieper' ecosystems. Publishing house Cherniavskyi D. [in Ukrainian]

Marchyshyn, S. M., Sira, L. M., \& Milian, I. I. (2015). Morphologica and anatomical structure of Veronica prostrata (Veronica prostrata L.). Ukrainian Biopharmaceutical Journal, 3(38), 78-82. [in Ukrainian]

Nedukha, O. M. (2015). Plant cell wall and environment. Alterpress. [in Ukrainian]

Nestrogayeva, E. N. (2011). Genus Veronica L. Scrophulariaceae Juss. in the flora of the Russian Caucasus and its analysis. [Abstract of thesis for the scientific degree of Candidate in Biological Sciences, Stavropol State University]. [in Russian]
Prykhodko, M. M. (2013). Ecological safety of natural and anthropogenically modified geosystems: monograph. Center for Environmental Education and Information. [in Ukrainian]

Pryluts'kyy, Yu. I., Il'chenko, O. V., Tsymbalyuk, O. V., \& Kosterin, S. O. (2017). Statistical methods in biology: textbook. Naukova Dumka. [in Ukrainian]

Raspisaniye Pogodi Ltd. (2020, December 20). Reliable Prognosis. http://rp5.ua.

Raunkiaer, C. (1934). The Life Forms of Plants and Statistical Plant Geography. Oxford University Press, London.

Shao, H.-B., Chu, L.-Ye, Jaleel, Ch. A., \& Zhao Ch.-X. (2008). Water-deficit stress-induced anatomical changes in higher plants. Comptes Rendus Biologies, 331, 215-225. https://doi.org/10.1016/j. crvi.2008.01.002

Shvets, I.V. (2013). Composition and distribution of species of the genus Veronica (Veronica L.) in Kyiv and Kyiv region. Scientific Bulletin of the National University of Life and Environmental Sciences of Ukraine. Series: Biology, Biotechnology, Ecology, 193, 38-44. [in Ukrainian with English summary]

Sjöman, H., Bellan, P., Hitchmough, J., \& Oprea A. (2015). Herbaceous plants for climate adaptation and intensely developed urban sites in Northern Europe: a case study from the Eastern Romanian Steppe. Ekológia (Bratislava), 34(1), 39-53. https://doi. org/10.1515/eko-2015-0005

Solomko, O. B., Klochkova, O. S., \& Tsvetkov, G. V. (2011). Method for determining the area of leaves. Retrieved January 7, 2020, from http://agrosbornik.ru/innovacii1/106-2011-10-09-15-29-31.htm [in Russian]

Takhtadzhyan, A. L. (1978). Floristic areas of the Earth. Science. [in Russian]

Verslues, P. E., Agarwal, M., Katiyar-Agarwal, S., Zhu, J., \& Zhu J.-K. (2006). Methods and concepts in quantifying resistance to drought, salt and freezing, abiotic stresses that affect plant water status. The Plant Journal, 45(4), 523-539. https://doi.org/10.1111/j.1365313X.2005.02593.x

Voitiuk, Yu. O., Kucheryava, L. V., Badanina, V. A., \& Brayon, O.V. (1998). Plant morphology with basics of anatomy and cytoembryology. Phytosociocenter. [in Ukrainian]

Wahid, A., Gelani, S., Ashraf, M., \& Foolad, M. R. (2007). Heat tolerance in plants: an overview. Environmental and Experimental Botany, 61, 199-223. https://doi.org/10.1016/j.envexpbot.2007.05.011

Wang, J.-Ch., Pan, B.-R., \& Albach, D. C. (2016). Evolution of morphological and climatic adaptations in Veronica L. (Plantaginaceae). Peer J-Life \& Environment, 4, Article e2333. https://doi.org/10.7717/peerj.2333

Yegorshyn, O. O., \& Lisovyi, M. V. (2005). Mathematical planning of field experiments and statistical processing of experimental data. Institute of Soil Science and Agrochemistry O.N. Sokolovsky. [in Ukrainian]

Yeremeiev, V., \& Yefimov, V. (2003). Regional aspects of global climate change. News of Ukrainian Academy of Sciences, 2, 24-28. [in Ukrainian].

Zamski, E., Orna, U., \& Koller, D. (1983). The mechanism of root contraction in Gymnarrhena micranatha, a desert plant. New Phytologist, 95(1), 29-35. https://doi.org/10.1111/j.1469-8137.1983. tb03465.x 